\title{
Identifying the need for simplification of type 2 diabetes mellitus treatment in residents of aged-care facilities: a meta-analysis and systematic review of the literature
}

\author{
LOWRI H THOMAS, ${ }^{1}$ PHILIP MS EVANS, ${ }^{2}$ ATUL KALHAN ${ }^{2}$
}

\begin{abstract}
Background: The management of type 2 diabetes mellitus (T2DM) in frail older adults is made challenging by the impact of physical and cognitive decline on self-monitoring of blood glucose (BG), administration of medications, especially injectable therapies, and risk of hypoglycaemia.

Aims and objectives: (1) To revisit the prevalence of hypoglycaemia in adults with T2DM living in aged-care facilities; (2) to evaluate the impact of simplification of T2DM treatment on quality of life (QOL), morbidity and mortality in this population; and (3) to identify higher risk older adults in whom simplification of therapy will be most appropriate.

Methods: MEDLINE was searched using the following concept areas: aged-care facilities, T2DM, anti-diabetic therapies, morbidity, mortality and QOL. Results (and additional literature identified by citation checking) were screened and assessed against pre-defined eligibility criteria. Standardised structures for extracting, appraising and reporting the literature were used.

Results: Hypoglycaemia is common in adults with T2DM in aged-care facilities. Glycated haemoglobin $\left(\mathrm{HbA}_{1 \mathrm{c}}\right)$ needs to be interpreted cautiously in this cohort, with additional capillary BG monitoring needed to identify individuals at risk of hypo- or hyperglycaemia. Simplification of T2DM treatment can reduce morbidity and mortality in frail older adults.
\end{abstract}

Conclusion: In residents of aged-care facilities, simplification

Cardiff University School of Medicine, Cardiff University, Cardiff, UK Department of Diabetes and Endocrinology, Royal Glamorgan Hospital, Llantrisant, UK

Address for correspondence: Professor Atul Kalhan Department of Diabetes and Endocrinology, Royal Glamorgan Hospital, Cwm Taf Morgannwg University Health Board, Ynysymaerdy, Llantristant CF27 8XR, UK

Telephone: 01443443443 ext.3665

E-mail: atul.kalhan@wales.nhs.uk

https://doi.org/10.15277/bjd.2021.290 of T2DM treatment can help deliver optimal individualised patient-centred care and improve QOL.

Br J Diabetes 2021;21:11-19

Key words: type 2 diabetes mellitus, aged-care facilities, frailty, dementia

\section{Introduction}

Type 2 diabetes mellitus (T2DM) is a significant global healthcare issue - a challenge intensified by our ageing population. ${ }^{1}$ By 2030 , 5.5 million people in the UK will have $\mathrm{T}_{2} \mathrm{DM}{ }^{2}$ affecting $17 \%$ of those aged over 75 years. ${ }^{3}$

For older adults with T2DM, co-morbidities, polypharmacy and decreased functional reserve equates to greater personal and economic burden of disease: older adults are disproportionally affected by disease complications and hypoglycaemia, which can further impair quality of life (QOL) and accentuate physical and cognitive dependence. ${ }^{4}$

The global prevalence of T2DM in aged-care facilities (including residential and nursing homes) is estimated at $25-33 \% .{ }^{4}$ Compared with age- and sex-matched controls, residents with T2DM experience accelerated physical and cognitive decline with increased hospital admissions, rapid acquisition of the frail phenotype and reduced life expectancy. ${ }^{4}$ Paradoxically, intensive glycaemic control, especially hypoglycaemia, is known to contribute to this decline. ${ }^{4}$ The International Diabetes Federation (IDF) recommends a glycated haemoglobin $\left(\mathrm{HbA}_{1 \mathrm{c}}\right)$ of $53-64 \mathrm{mmol} / \mathrm{mol}$ in functionally dependent older adults, with lenience to $<70 \mathrm{mmol} / \mathrm{mol}$ in individuals with frailty or dementia. ${ }^{5}$ This less intensive glycaemic target aims to balance vascular benefits against the risk of hypoglycaemia in older adults. ${ }^{5} \mathrm{HbA}_{1 \mathrm{c}}$ represents the average glycaemic control over an 8-12-week period and is not an ideal parameter for evaluating day-to-day fluctuation in blood glucose (BG) levels. Additionally, anaemia, haemoglobinopathies and renal impairment are relatively more common amongst older adults, resulting in a less reliable marker of glycaemic control in this cohort.

Hypoglycaemia is common and under-recognised in residents of aged-care facilities. ${ }^{4}$ This may reflect the dynamic nature of diabetes: disease and age-related changes to body composition, renal 
and hepatic dysfunction, reduced nutrition and cognitive impairment result in an increased risk of hypoglycaemia and an impaired ability to respond to lower BG levels. A re-evaluation of glycaemic targets and simplification of treatment can mitigate the risks posed by intensive therapeutic regimens.

Over the last decade, novel oral glucose-lowering therapies have offered simplified treatments and additional cardiovascular and renovascular benefits. ${ }^{6}$ However, long-term data outcomes on their safety and efficacy in frail older adults are still to be robustly established.

\section{Aims and objectives}

We aimed to evaluate hypoglycaemia prevalence and $\mathrm{HbA}_{1 \mathrm{c}}$ levels as semi-quantitative evidence of overtreatment in residents of aged-care facilities. In addition, we carried out a retrospective review of the literature to evaluate the impact of simplification of T2DM treatment on morbidity, mortality and QOL in this population. Finally, we suggest a possible approach to identify higher risk older adults in whom simplification of therapy will be most appropriate.

\section{Methods}

\section{Searching the literature}

In April 2020 the MEDLINE database was searched using text word and subject heading functions. The search incorporated the following concept areas: aged-care facilities, T2DM, anti-diabetic therapies, simplification of therapy, morbidity, mortality and QOL. Aged-care facilities include both residential and nursing homes. Appendix 1 (online at www.bjd-abcd.com) details the full search strategy used.

\section{Selecting the literature}

Results and additional literature identified through citation checking were screened by title and abstract to exclude literature clearly irrelevant to review. Thereafter, full-text articles were assessed against the following pre-defined eligibility criteria.

Inclusion criteria:

- Evaluates T2DM treatment in residents of aged-care facilities

- Observational or interventional study exploring the impact of simplification of T2DM treatment on morbidity, mortality and QOL

- Observational or interventional study exploring approaches to identify higher risk older adults in whom simplification of therapy will be most appropriate

\section{Exclusion criteria:}

- Non-English literature

- Non-peer reviewed literature

- Literature reviews, guidelines, opinions or editorials

\section{Extracting, appraising and reporting the literature}

Data extraction was guided by the Cochrane Collaboration's template for data extraction. ${ }^{7}$ The Critical Appraisal Skills Programme checklists ${ }^{8}$ were used to guide appraisal while the write-up of this review was supported by the Preferred Reporting Items for Systematic Reviews and Meta-Analyses (PRISMA) checklist. ${ }^{9}$

\section{Results}

The search strategy yielded 88 results. Following screening by title and abstract, 27 records clearly irrelevant to review were excluded. The remaining 61 full-text articles were assessed for eligibility against the criteria detailed above. Of these, 43 records were excluded. These included 15 records not reflective of review focus, 13 literature reviews, guidelines, opinions or editorials, 10 inaccessible records, and 5 non-English studies (see Figure 1). The remaining 18 studies are included in this review.

We identified 18 studies which evaluated the prevalence of hypoglycaemia and the need for simplification in residents with T2DM in aged-care facilities (see Table 1). ${ }^{10-27}$ Based on a retrospective

Figure 1. Adapted PRISMA flow diagram ${ }^{9}$ detailing results of methodology.

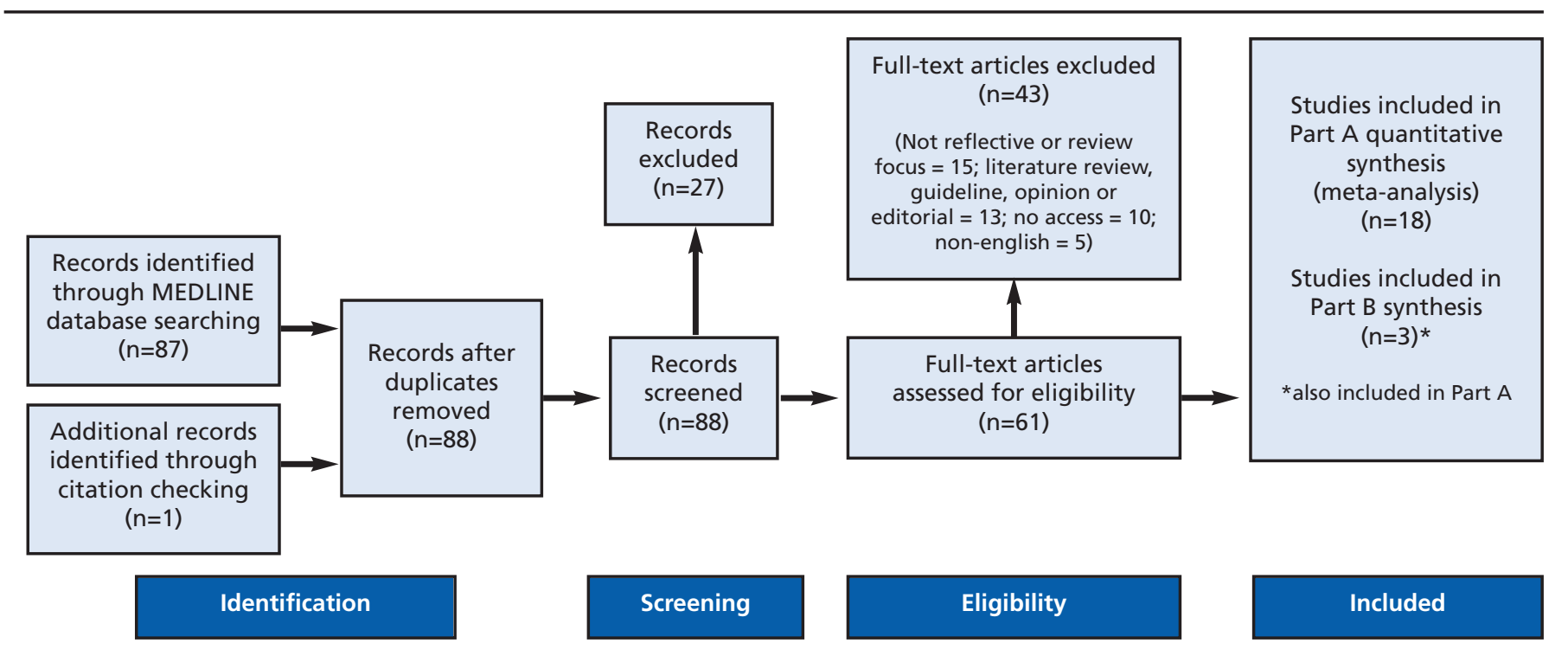


Table 1 Evaluating the need for simplification of T2DM treatment in residents of aged-care facilities

\begin{tabular}{|c|c|c|c|c|c|}
\hline Study details & Study overview & Study desic & & Key results & Comments \\
\hline $\begin{array}{l}\text { Niznik et al, } \\
2020^{10}\end{array}$ & $\begin{array}{l}\text { To explore predictors for } \\
\text { diabetes treatment } \\
\text { deintensification }\end{array}$ & $\begin{array}{l}\text { Sample size } \\
\text { Intervention } \\
\text { Outcome; } \\
\text { Comparison }\end{array}$ & $\begin{array}{l}\text { Retrospective cohort study } \\
\text { Veteran nursing home } \\
\text { residents with advanced } \\
\text { dementia or perceived to be } \\
\text { at end of life } \\
\mathrm{n}=6960 \\
\text { Nil } \\
\text { Deintensification of diabetes } \\
\text { medication; nil }\end{array}$ & $\begin{array}{l}40 \% \text { overtreated; } 46 \% \\
\text { deintensified at } 90 \text { days. } \\
\text { Predictors for deintensification: } \\
\text { end of life, non-metformin OAD. } \\
\text { Predictors against } \\
\text { deintensification: high } \mathrm{HbA}_{1 \mathrm{c}} \text {, } \\
\text { insulin, obesity, peripheral arterial } \\
\text { disease. }\end{array}$ & $\begin{array}{l}\text { Quantifies overtreatment and } \\
\text { poor deintensification; insulin } \\
\text { as predictor against } \\
\text { deintensification may reflect } \\
\text { type } 1 \text { or Latent Autoimmune } \\
\text { Diabetes of Adulthood } \\
\text { (LADA). }\end{array}$ \\
\hline $\begin{array}{l}\text { Umpierrez et al, } \\
2018^{11}\end{array}$ & $\begin{array}{l}\text { To explore outcomes of } \\
\text { simplifying diabetes } \\
\text { treatment with glargine } \\
\text { or linagliptin } \\
\text { monotherapy }\end{array}$ & $\begin{array}{l}\text { Type } \\
\text { Population } \\
\text { Sample size } \\
\text { Intervention } \\
\text { Outcome; } \\
\text { Comparison }\end{array}$ & $\begin{array}{l}\text { Open-label randomised } \\
\text { controlled trial } \\
\text { Aged-care facility residents on } \\
\mathrm{OAD} \text { or low-dose insulin and } \\
\mathrm{HbA}_{1 c}>58 \mathrm{mmol} / \mathrm{mol} \\
\mathrm{n}=140 \\
\text { Glargine monotherapy or } \\
\text { linagliptin monotherapy } \\
\text { Mean daily BG, hypoglycaemia, } \\
\mathrm{HbA}_{1 c} \text {, hospital admission, } \\
\text { emergency department visits; } \\
\text { baseline, glargine monotherapy, } \\
\text { linagliptin monotherapy }\end{array}$ & $\begin{array}{l}\text { Significantly lower mean daily } \\
\text { BG with linagliptin and glargine } \\
\text { monotherapy compared with } \\
\text { baseline. } 34 \% \text { absolute risk } \\
\text { reduction in hypoglycaemia with } \\
\text { linagliptin compared with } \\
\text { glargine. No significant difference } \\
\text { in } \mathrm{HbA}_{1 c} \text { at } 6 \text { months between } \\
\text { linagliptin and glargine. No } \\
\text { significant changes to all-cause } \\
\text { hospital admissions in any } \\
\text { intervention. }\end{array}$ & $\begin{array}{l}\text { Demonstrates safety and } \\
\text { efficacy of linagliptin } \\
\text { monotherapy for } \\
\text { simplification of diabetes } \\
\text { treatment. }\end{array}$ \\
\hline $\begin{array}{l}\text { McCracken et al, } \\
2017^{12}\end{array}$ & $\begin{array}{l}\text { To evaluate relationship } \\
\text { between polypharmacy } \\
\text { and overtreatment }\end{array}$ & $\begin{array}{l}\text { Type } \\
\text { Population } \\
\text { Sample size } \\
\text { Intervention } \\
\text { Outcome; } \\
\text { Comparison }\end{array}$ & $\begin{array}{l}\text { Cross-sectional observational study } \\
\text { Aged-care facility residents } \\
n=214 \\
\text { Nil } \\
\text { Number of prescribed } \\
\text { medications, } \mathrm{HbA}_{1} \text {; nil }\end{array}$ & $\begin{array}{l}48 \% \text { met definition for } \\
\text { polypharmacy. } \\
\text { Those with overtreated diabetes } \\
\text { prescribed more antidiabetic } \\
\text { treatment than those with higher } \\
\mathrm{HbA}_{1 \mathrm{c}} \text {. }\end{array}$ & $\begin{array}{l}\text { Polypharmacy common and } \\
\text { contributes to functional } \\
\text { decline. No significant } \\
\text { relationship between number } \\
\text { of prescribed medications and } \\
\text { overtreatment. }\end{array}$ \\
\hline $\begin{array}{l}\text { Retornaz et al, } \\
2017^{13}\end{array}$ & $\begin{array}{l}\text { To evaluate relationship } \\
\text { between } \mathrm{HbA}_{1 \mathrm{c}} \text { and } \\
\text { hypoglycaemia risk }\end{array}$ & $\begin{array}{l}\text { Type } \\
\text { Population } \\
\text { Sample size } \\
\text { Intervention } \\
\text { Outcome; } \\
\text { Comparison }\end{array}$ & $\begin{array}{l}\text { Cross-sectional observational study } \\
\text { Aged-care facility residents with } \\
\text { diabetes } \\
n=236 \\
\text { Nil } \\
\mathrm{HbA}_{1 \text { c }} \text {, hypoglycaemia; nil }\end{array}$ & $\begin{array}{l}\text { Intensive glycaemic control in } \\
60 \% \text {. } \\
19 \% \text { affected by hypoglycaemia. } \\
\text { Hypoglycaemia and sub-optimal } \\
\text { glycaemic control more common } \\
\text { in those taking insulin therapy. } \\
\text { No significant correlation } \\
\text { between } \mathrm{HbA}_{1 c} \text { and } \\
\text { hypoglycaemia. }\end{array}$ & $\begin{array}{l}\text { Identifies insulin therapy as } \\
\text { most requiring review and } \\
\text { simplification. HbA } 1 \text { c levels } \\
\text { not sufficient for } \\
\text { hypoglycaemia risk detection. } \\
\text { Capillary BG monitoring } \\
\text { warranted in nursing home } \\
\text { residents. }\end{array}$ \\
\hline $\begin{array}{l}\text { Walfridsson et al, } \\
2016^{14}\end{array}$ & $\begin{array}{l}\text { To investigate clinical } \\
\text { characteristics and } \\
\text { prevalence of } \\
\text { hypoglycaemia }\end{array}$ & $\begin{array}{l}\text { Type } \\
\text { Population } \\
\text { Sample size } \\
\text { Intervention } \\
\text { Outcome; } \\
\text { Comparison }\end{array}$ & $\begin{array}{l}\text { Cross-sectional observational study } \\
\text { Aged-care facility residents } \\
\text { with diabetes } \\
n=1350 \\
\mathrm{Nil} \\
\mathrm{HbA}_{1 \text { c, hypoglycaemia, diabetic }} \\
\text { complications; nil }\end{array}$ & $\begin{array}{l}\text { Mean } \mathrm{HbA}_{1 c} 56.0 \mathrm{mmol} / \mathrm{mol} \text {. } \\
43 \% \text { with } \mathrm{Hb} \mathrm{A}_{1 c}<52 \mathrm{mmol} / \mathrm{mol} \text {. } \\
24 \% \text { affected by hypoglycaemia. }\end{array}$ & $\begin{array}{l}43 \% \text { overtreated based on IDF } \\
\mathrm{Hb} \mathrm{A}_{1 \mathrm{c}} \text { targets in this } \\
\text { population. } \\
\text { Hypoglycaemia common. }\end{array}$ \\
\hline $\begin{array}{l}\text { Dharmarajan } \\
\text { et al, } 2016^{15}\end{array}$ & $\begin{array}{l}\text { To compare safety and } \\
\text { efficacy of BB and SS } \\
\text { insulin regimens }\end{array}$ & $\begin{array}{l}\text { Type } \\
\text { Population } \\
\text { Sample size } \\
\text { Intervention } \\
\text { Outcome; } \\
\text { Comparison }\end{array}$ & $\begin{array}{l}\text { Randomised controlled trial } \\
\text { Aged-care facility residents } \\
\text { with diabetes } \\
n=64 \\
\text { SS insulin regimen, BB insulin } \\
\text { regimen } \\
\text { Fasting BG, hypoglycaemia, } \\
\text { hyperglycaemia, adverse events; } \\
\text { BB and SS }\end{array}$ & $\begin{array}{l}\text { Significantly lower fasting BG in } \\
\text { those on BB insulin regimens } \\
\text { compared to SS. } \\
\text { No significant differences in the } \\
\text { incidence of hypoglycaemia. }\end{array}$ & $\begin{array}{l}\text { Simplified insulin regimen } \\
\text { improves fasting BG. } \\
\text { Three-day data collection } \\
\text { period not adequate for } \\
\text { observation of hypoglycaemic } \\
\text { events. } \\
\text { Evidence of safety and efficacy } \\
\text { of simplified insulin regimens. }\end{array}$ \\
\hline Bo et al, $2015^{16}$ & $\begin{array}{l}\text { To investigate clinical } \\
\text { characteristics and } \\
\text { prevalence of } \\
\text { hypoglycaemia }\end{array}$ & $\begin{array}{l}\text { Type } \\
\text { Population } \\
\text { Sample size } \\
\text { Intervention } \\
\text { Outcome; } \\
\text { Comparison }\end{array}$ & $\begin{array}{l}\text { Cross-sectional observational study } \\
\text { Aged-care facility residents } \\
\text { with diabetes } \\
\mathrm{n}=863 \\
\text { Nil } \\
\text { Cognitive and functional } \\
\text { dependence, } \mathrm{HbA}_{1 \mathrm{c}} \\
\text { hypoglycaemia }\end{array}$ & $\begin{array}{l}\text { Cognitive impairment, functional } \\
\text { dependence and co-morbidities } \\
\text { are common among residents } \\
\text { with diabetes. } \\
55 \% \text { with } \mathrm{HbA}_{1 \mathrm{c}}<53 \mathrm{mmol} / \mathrm{mol} \text {. } \\
6.6 \% \text { experience hypoglycaemia. }\end{array}$ & $\begin{array}{l}\text { Individuals who are frail and } \\
\text { have dementia are particularly } \\
\text { at risk of overtreatment. } \\
55 \% \text { overtreated based on IDF } \\
\mathrm{HbA}_{1 \mathrm{c}} \text { targets in this } \\
\text { population. }\end{array}$ \\
\hline
\end{tabular}


Table 1 Evaluating the need for simplification of T2DM treatment in residents of aged-care facilities (continued)

\begin{tabular}{|c|c|c|c|c|c|}
\hline \multirow{2}{*}{$\begin{array}{l}\text { Study details } \\
\text { Neumark et al, } \\
2016^{17}\end{array}$} & \multirow[b]{2}{*}{$\begin{array}{l}\text { Study overview } \\
\text { To explore clinical } \\
\text { characteristics of older } \\
\text { people with diabetes } \\
\text { living at home (with and } \\
\text { without additional care) } \\
\text { and in nursing care } \\
\text { homes }\end{array}$} & \multicolumn{2}{|c|}{ Study design } & \multirow[b]{2}{*}{$\begin{array}{l}\text { Key results } \\
\text { Lower } \mathrm{HbA}_{1 \mathrm{c}} \text { in residents of } \\
\text { nursing homes. } \\
\mathrm{HbA}_{1 \mathrm{c}}<52 \mathrm{mmol} / \mathrm{mol} \text { in } 48 \% \text { of } \\
\text { nursing homes residents, } 35 \% \text { of } \\
\text { those living at home with } \\
\text { additional care, and } 29 \% \text { of } \\
\text { those living at home } \\
\text { independently. Insulin use more } \\
\text { prevalent in nursing care homes. }\end{array}$} & \multirow{2}{*}{$\begin{array}{l}\text { Comments } \\
48 \% \text { overtreated based on } \\
\text { IDF HbA } 1 \text { c targets in this } \\
\text { population. }\end{array}$} \\
\hline & & $\begin{array}{l}\text { Type } \\
\text { Population } \\
\text { Sample size } \\
\text { Intervention } \\
\text { Outcome; } \\
\text { Comparison }\end{array}$ & $\begin{array}{l}\text { Cross-sectional observational study } \\
\text { Aged } \geq 80 \text { with diabetes } \\
n=277 \\
\mathrm{Nil} \\
\mathrm{HbA}_{1} \text {; residing at home, residing } \\
\text { in residential care homes, residing } \\
\text { in nursing care homes }\end{array}$ & & \\
\hline $\begin{array}{l}\text { Abatecola et al, } \\
2015^{18}\end{array}$ & $\begin{array}{l}\text { To investigate clinical } \\
\text { characteristics and } \\
\text { prevalence of } \\
\text { hypoglycaemia }\end{array}$ & $\begin{array}{l}\text { Type } \\
\text { Population } \\
\text { Sample size } \\
\text { Intervention } \\
\text { Outcome; } \\
\text { Comparison }\end{array}$ & $\begin{array}{l}\text { Cross-sectional observational study } \\
\text { Aged-care facility residents with } \\
\text { diabetes } \\
n=2258 \\
\text { Nil } \\
\text { Fasting BG, postprandial BG, } \\
\text { HbA }_{1 c} \text {, ADLs; anti-diabetic } \\
\text { treatments }\end{array}$ & $\begin{array}{l}\text { Hypoglycaemia observed in } 18 \% \\
\text { of nursing home residents with } \\
\text { dementia compared to } 8 \% \text { in } \\
\text { residents without dementia. } \\
\text { Residents on sulfonylurea therapy } \\
\text { had increased odds ratio ( } 8.8, \\
\mathrm{Cl} 4.2 \text { to } 18.2 \text { ) of severe } \\
\text { hypoglycaemia. Rapid and } \\
\text { analogue insulin therapy } \\
\text { associated with reduced odds } \\
\text { ratio }(0.333, \mathrm{Cl} 0.184 \text { to } 0.602 \\
\text { and } 0.248, \mathrm{Cl} 0.070 \text { to } 0.882 \\
\text { respectively) of severe } \\
\text { hypoglycaemia. }\end{array}$ & $\begin{array}{l}\text { Individuals with dementia are } \\
\text { particularly at risk of } \\
\text { hypoglycaemia. Cautious use } \\
\text { of sulfonylurea therapy } \\
\text { required. Rapid and analogue } \\
\text { insulin therapy relatively safer. }\end{array}$ \\
\hline $\begin{array}{l}\text { Andreassen et al, } \\
2014^{19}\end{array}$ & $\begin{array}{l}\text { To investigate clinical } \\
\text { characteristics and } \\
\text { prevalence of } \\
\text { hypoglycaemia }\end{array}$ & $\begin{array}{l}\text { Type } \\
\text { Population } \\
\text { Sample size } \\
\text { Intervention } \\
\text { Outcome; } \\
\text { Comparison }\end{array}$ & $\begin{array}{l}\text { Cross-sectional observational study } \\
\text { Aged-care facility residents with } \\
\text { diabetes } \\
n=742 \\
\text { Nil } \\
\mathrm{HbA}_{1 \text { c; }} \text { nil }\end{array}$ & 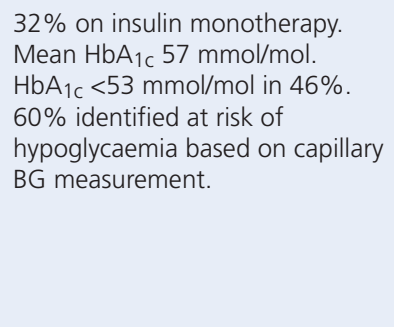 & $\begin{array}{l}\text { Insulin therapy common - } \\
\text { proportion who are insulin } \\
\text { dependent unknown. } \\
46 \% \text { overtreated based on IDF } \\
\mathrm{HbA}_{1 c} \text { targets in this } \\
\text { population. } \\
\text { Capillary BG measurement has } \\
\text { a broader reach to identify } \\
\text { those at risk of developing } \\
\text { hypoglycaemia. }\end{array}$ \\
\hline $\begin{array}{l}\text { Sjoblom et al, } \\
2008^{21}\end{array}$ & $\begin{array}{l}\text { To compare safety and } \\
\text { efficacy of } \\
\text { deintensification of } \\
\text { diabetes treatment }\end{array}$ & $\begin{array}{l}\text { Type } \\
\text { Population } \\
\text { Sample size } \\
\text { Intervention }\end{array}$ & $\begin{array}{l}\text { Open-label non-randomised } \\
\text { controlled trial } \\
\text { Aged-care facility residents with } \\
\text { diabetes and } \mathrm{HbA} \mathrm{A}_{1 \mathrm{c}} \\
\leq 42 \mathrm{mmol} / \mathrm{mol} \\
\mathrm{n}=98 \\
\text { Cessation of OADs, cessation of } \\
\text { insulin }<20 \text { units and halving of } \\
\text { insulin }>20 \text { units } \\
\mathrm{HbA}_{1 c} \text {, hypoglycaemia; baseline }\end{array}$ & $\begin{array}{l}6 \text {-month } 7 \mathrm{mmol} / \mathrm{mol} \text { mean } \\
\mathrm{HbA}_{1 \mathrm{c}} \text { increase in those } \\
\text { undergoing deintensification. } \\
6 \text {-month post-intervention mean } \\
\text { remained low at } 40 \mathrm{mmol} / \mathrm{mol} \text {. } \\
\text { Deintensification caused no } \\
\text { significant changes to all-cause } \\
\text { hospital admissions or mortality. }\end{array}$ & $\begin{array}{l}\text { Demonstrates safety and } \\
\text { efficacy of deintensification of } \\
\text { diabetes treatment. }\end{array}$ \\
\hline $\begin{array}{l}\text { Meyers et al, } \\
2007^{22}\end{array}$ & $\begin{array}{l}\text { To investigate variability } \\
\text { of } \mathrm{HbA}_{1 c}\end{array}$ & $\begin{array}{l}\text { Type } \\
\text { Population } \\
\text { Sample size } \\
\text { Intervention } \\
\text { Outcome; } \\
\text { Comparison }\end{array}$ & $\begin{array}{l}\text { Cross-sectional observational study } \\
\text { Aged-care facility residents with } \\
\text { diabetes } \\
n=168 \\
\mathrm{Nil} \\
\mathrm{HbA}_{1} \text {; } \text {; nil }\end{array}$ & $\begin{array}{l}\text { Mean } \mathrm{HbA}_{1 \mathrm{c}} 54.1 \mathrm{mmol} / \mathrm{mol} \text {. } \\
\text { Age correlation with } \mathrm{HbA} \mathrm{A}_{1 \mathrm{c}} \\
\text { lowest among the oldest. } \\
\text { Higher } \mathrm{HbA} 1 \mathrm{c} \text { with insulin use. } \\
\text { No correlation between } \mathrm{HbA}_{1 \mathrm{c}} \\
\text { and self-perceived health and life } \\
\text { expectancy. }\end{array}$ & $\begin{array}{l}\text { Suggests the oldest and } \\
\text { frailest at increased risk of } \\
\text { hypoglycaemia. } \\
\mathrm{HbA}_{1 \mathrm{c}} \text { may not have } \\
\text { self-perceived impact on } \\
\text { quality of life. }\end{array}$ \\
\hline
\end{tabular}


Table 1 Evaluating the need for simplification of T2DM treatment in residents of aged-care facilities (continued)

\begin{tabular}{|c|c|c|c|c|c|}
\hline \multirow{2}{*}{$\begin{array}{l}\text { Study details } \\
\text { Gill et al, } 2006^{23}\end{array}$} & \multirow{2}{*}{$\begin{array}{l}\text { Study overview } \\
\text { To investigate clinical } \\
\text { characteristics and } \\
\text { glycaemic control }\end{array}$} & \multicolumn{2}{|c|}{ Study design } & \multirow{2}{*}{$\begin{array}{l}\text { Key results } \\
\text { Mean } \mathrm{HbA}_{1 \mathrm{c}} 56 \mathrm{mmol} / \mathrm{mol} \text {. } \\
\text { Co-morbidities and } \\
\text { polypharmacy common. } \\
27 \% \text { on insulin. }\end{array}$} & \multirow{2}{*}{$\begin{array}{l}\text { Comments } \\
\text { Co-morbidities and } \\
\text { polypharmacy contribute to } \\
\text { disease and age-mediated } \\
\text { decline. } \\
\text { Insulin therapy common - } \\
\text { proportion who are insulin } \\
\text { dependent unknown. }\end{array}$} \\
\hline & & $\begin{array}{l}\text { Type } \\
\text { Population } \\
\text { Sample size } \\
\text { Intervention } \\
\text { Outcome; } \\
\text { Comparison }\end{array}$ & $\begin{array}{l}\text { Cross-sectional observational study } \\
\text { Aged-care facility residents with } \\
\text { diabetes } \\
\mathrm{n}=54 \\
\mathrm{Nil} \\
\mathrm{HbA}_{1 \text { c }} \text {; nil }\end{array}$ & & \\
\hline $\begin{array}{l}\text { Pham et al, } \\
2003^{24}\end{array}$ & $\begin{array}{l}\text { To investigate clinical } \\
\text { characteristics and } \\
\text { outcomes }\end{array}$ & $\begin{array}{l}\text { Type } \\
\text { Population } \\
\text { Sample size } \\
\text { Intervention } \\
\text { Outcome; } \\
\text { Comparison }\end{array}$ & $\begin{array}{l}\text { Cross-sectional observational study } \\
\text { Aged-care facility residents with } \\
\text { diabetes } \\
\begin{array}{l}n=240 \text { nursing home residents; } \\
n=80 \text { residential home residents } \\
\text { Nil }\end{array}\end{array}$ & $\begin{array}{l}\text { Insulin treatment in } 36 \% \text {. } \\
\text { OAD in } 40 \% \text {. }\end{array}$ & $\begin{array}{l}\text { Insulin therapy common - } \\
\text { proportion who are insulin } \\
\text { dependent unknown. }\end{array}$ \\
\hline $\begin{array}{l}\text { Wolffenbuttel } \\
\text { et al, } 1991^{25}\end{array}$ & $\begin{array}{l}\text { Investigate clinical } \\
\text { characteristics and } \\
\text { outcomes of aged-care } \\
\text { facility residents with } \\
\text { diabetes }\end{array}$ & $\begin{array}{l}\text { Type } \\
\text { Population } \\
\text { Sample size } \\
\text { Intervention } \\
\text { Outcome; } \\
\text { Comparison }\end{array}$ & $\begin{array}{l}\text { Cross-sectional observational study } \\
\text { Aged-care facility residents with } \\
\text { diabetes } \\
n=38 \\
\mathrm{Nil} \\
\mathrm{HbA}_{1 c} \text {, diabetic complications; nil }\end{array}$ & $\begin{array}{l}\text { Mean } \mathrm{HbA}_{1 \mathrm{c}} 58 \mathrm{mmol} / \mathrm{mol} \text {. } \\
\text { No difference between } \mathrm{HbA}_{1 \mathrm{c}} \text { in } \\
\text { those with diabetes in the } \\
\text { community or in aged-care } \\
\text { facilities. } \\
\text { Those in aged-care facilities more } \\
\text { likely to experience general } \\
\text { decline: ulcers, necrosis, recurrent } \\
\text { infections, peripheral arterial } \\
\text { disease. }\end{array}$ & $\begin{array}{l}\text { Emphasises general propensity } \\
\text { towards frailty in residents of } \\
\text { aged-care facilities. }\end{array}$ \\
\hline $\begin{array}{l}\text { Davis et al, } \\
2014^{26}\end{array}$ & $\begin{array}{l}\text { Investigate clinical } \\
\text { characteristics and } \\
\text { outcomes of individuals } \\
\text { receiving basal insulin }\end{array}$ & $\begin{array}{l}\text { Type } \\
\text { Population } \\
\text { Sample size } \\
\text { Intervention } \\
\text { Outcome; } \\
\text { Comparison }\end{array}$ & $\begin{array}{l}\text { Retrospective observational study } \\
\text { Aged-care facility residents with } \\
\text { diabetes } \\
n=2096 \\
\text { Nil } \\
\text { Hypoglycaemia; nil }\end{array}$ & $\begin{array}{l}60 \% \text { of residents receive insulin } \\
\text { therapy. } \\
17 \% \text { affected by hypoglycaemia. }\end{array}$ & $\begin{array}{l}\text { Insulin therapy common - } \\
\text { proportion who are insulin } \\
\text { dependent unknown. } \\
\text { Hypoglycaemia relatively } \\
\text { common. Basal insulin } \\
\text { under-utilised. }\end{array}$ \\
\hline $\begin{array}{l}\text { Newton et al, } \\
2013^{27}\end{array}$ & $\begin{array}{l}\text { To determine clinical } \\
\text { characteristics by } \\
\text { antidiabetic therapy }\end{array}$ & $\begin{array}{l}\text { Type } \\
\text { Population } \\
\text { Sample size } \\
\text { Intervention } \\
\text { Outcome; } \\
\text { Comparison }\end{array}$ & $\begin{array}{l}\text { Cross-sectional observational study } \\
\text { Aged-care facility residents with } \\
\text { diabetes } \\
\mathrm{n}=1409 \\
\mathrm{Nil} \\
\text { Antidiabetic therapy }\end{array}$ & $\begin{array}{l}34 \% \text { received insulin, } 26 \% \\
\text { received insulin and OAD, } 5 \% \\
\text { on OAD alone, } 10 \% \text { diet- } \\
\text { controlled. }\end{array}$ & $\begin{array}{l}\text { Insulin therapy common - } \\
\text { proportion who are insulin } \\
\text { dependent unknown. }\end{array}$ \\
\hline
\end{tabular}

ADLs, activities of daily living; BB, basal bolus; BG, blood glucose; Cl, confidence interval; HbA1c, glycated haemoglobin; IDF, International Diabetes Federation; $\mathrm{OAD}$, oral antidiabetic drug; SS, sliding scale.

analysis of data from 10 observational studies, our systematic review suggests that hypoglycaemia remains common: hypoglycaemia was reported in 6.6-43\%, 10,11,13,14,16,18,19,24,26,27 clearly identifying it as a preventable factor contributing to increased morbidity and mortality in this cohort.

We could identify only three studies which evaluated a strategy for simplification of T2DM treatment in residents of aged-care facilities (see Table 2). Based on our meta-analysis, older adults with T2DM were more prone to experience hypoglycaemia at both ends of the $\mathrm{HbA}_{1 \mathrm{c}}$ spectrum. ${ }^{10,13,14}$

\section{Discussion}

\section{Part A: Evaluating the need for simplification of T2DM treatment in residents of aged-care facilities}

Management of T2DM in frail older adults poses special chal- lenges as a reduction in functional capacity, development of comorbidities, polypharmacy, cognitive decline and frailty warrants dynamic re-evaluation of glycaemic targets. The vascular benefits of intensive control need to be weighed against risks posed by hypoglycaemia, with focus on simplification of the therapeutic regimen and adaptation of an individualised approach.

Multiple observational and cross-sectional studies have investigated the prevalence of hypoglycaemia and used $\mathrm{HbA}_{1 \mathrm{c}}$ as a marker of glycaemic control. ${ }^{10-28}$ We identified 16 studies (collectively involving 7,869 aged-care residents with T2DM) in which data on $\mathrm{HbA}_{1 \mathrm{c}}$ were collected and compared to evaluate glycaemic control. Among these studies, the mean $\mathrm{HbA}_{1 \mathrm{c}}$ was $51.9 \mathrm{mmol} / \mathrm{mol}$ (95\% Cl 52.0 to $51.8 \mathrm{mmol} / \mathrm{mol})$; Figure 2$)$. However, of the five studies reporting grouped values, $\mathrm{HbA}_{1 \mathrm{c}}<53 \mathrm{mmol} / \mathrm{mol}$ was seen in $43-55 \% .{ }^{14-16,19,22}$ With the IDF recommending a target $\mathrm{HbA}_{1 \mathrm{c}}$ of 
Table 2 Simplification of type 2 diabetes mellitus treatment in aged-care facility residents

\begin{tabular}{|c|c|c|c|c|}
\hline Study details & Study overview & Study desig & & Key results \\
\hline $\begin{array}{l}\text { Umpierrez et al, } \\
2018^{11}\end{array}$ & $\begin{array}{l}\text { To explore outcomes } \\
\text { of simplifying diabetes } \\
\text { treatment with glargine } \\
\text { or linagliptin } \\
\text { monotherapy }\end{array}$ & $\begin{array}{l}\text { Type } \\
\text { Population } \\
\text { Sample size } \\
\text { Intervention } \\
\text { Outcome; } \\
\text { Comparison }\end{array}$ & $\begin{array}{l}\text { Open-label randomised controlled } \\
\text { trial } \\
\text { Aged-care facility residents on } \\
\text { OAD or low-dose insulin and } \\
\mathrm{HbA}_{1 \mathrm{c}}>58 \mathrm{mmol} / \mathrm{mol} \\
\mathrm{n}=140 \\
\text { Glargine monotherapy or } \\
\text { linagliptin monotherapy } \\
\text { Mean daily BG, hypoglycaemia, } \\
\text { HbA } 1 \text { c, hospital admission, } \\
\text { emergency department visits; } \\
\text { baseline, glargine monotherapy, } \\
\text { linagliptin monotherapy }\end{array}$ & $\begin{array}{l}\text { Significantly lower mean daily } \\
\text { BG with linagliptin and glargine } \\
\text { monotherapy compared with } \\
\text { baseline. } 34 \% \text { absolute risk } \\
\text { reduction in hypoglycaemia with } \\
\text { linagliptin compared with } \\
\text { glargine. No significant difference } \\
\text { in } \mathrm{HbA}_{1 \mathrm{c}} \text { at } 6 \text { months between } \\
\text { linagliptin and glargine. No } \\
\text { significant changes to all-cause } \\
\text { hospital admissions in any } \\
\text { intervention. }\end{array}$ \\
\hline $\begin{array}{l}\text { Dharmarajan } \\
\text { et al, 2016 }\end{array}$ & $\begin{array}{l}\text { To compare of safety } \\
\text { and efficacy of BB and } \\
\text { SS insulin regimens }\end{array}$ & $\begin{array}{l}\text { Type } \\
\text { Population } \\
\text { Sample size } \\
\text { Intervention } \\
\text { Outcome; } \\
\text { Comparison }\end{array}$ & $\begin{array}{l}\text { Randomised controlled trial } \\
\text { Aged-care facility residents with } \\
\text { diabetes } \\
\mathrm{n}=64 \\
\text { SS insulin regimen, BB insulin } \\
\text { regimen } \\
\text { Fasting BG, hypoglycaemia, } \\
\text { hyperglycaemia, adverse events; } \\
\text { BB and SS }\end{array}$ & $\begin{array}{l}\text { Significantly lower fasting BG in } \\
\text { those on BB insulin regimens } \\
\text { compared with SS. } \\
\text { No significant differences in the } \\
\text { incidence of hypoglycaemia. }\end{array}$ \\
\hline $\begin{array}{l}\text { Sjoblom et al, } \\
2008^{21}\end{array}$ & $\begin{array}{l}\text { To compare the safety } \\
\text { and efficacy of } \\
\text { deintensification of } \\
\text { diabetes treatment }\end{array}$ & $\begin{array}{l}\text { Type } \\
\text { Population } \\
\text { Sample size } \\
\text { Intervention } \\
\text { Outcome; } \\
\text { Comparison }\end{array}$ & $\begin{array}{l}\text { Open-label non-randomised } \\
\text { controlled trial } \\
\text { Aged-care facility residents with } \\
\text { diabetes and } \mathrm{HbA}_{1 \mathrm{c}} \leq 42 \mathrm{mmol} / \mathrm{mol} \\
\mathrm{n}=98 \\
\text { Cessation of } \mathrm{OADs} \text {, cessation of } \\
\text { insulin }<20 \text { units and halving of } \\
\text { insulin }>20 \text { units; } \\
\mathrm{HbA}_{1 c} \text {, hypoglycaemia; baseline }\end{array}$ & $\begin{array}{l}\text { 6-month } 7 \mathrm{mmol} / \mathrm{mol} \text { mean } \\
\mathrm{Hb} \mathrm{A}_{1 \mathrm{c}} \text { increase in those } \\
\text { undergoing deintensification. } \\
6 \text {-month post-intervention mean } \\
\text { remained low at } 40 \mathrm{mmol} / \mathrm{mol} \text {. } \\
\text { Deintensification caused no } \\
\text { significant changes to all-cause } \\
\text { hospital admissions or mortality. }\end{array}$ \\
\hline
\end{tabular}

\section{Comments}

Demonstrates safety and efficacy of linagliptin monotherapy for deintensification of diabetes treatment.
Simplified insulin regimen improves fasting BG. Three-day data collection period not adequate for observation of hypoglycaemic events.

Evidence of safety and efficacy of simplified insulin regimens.

Demonstrates safety and efficacy of deintensification of diabetes treatment.

\section{$\mathrm{BB}$, basal bolus; $\mathrm{BG}$, blood glucose; $\mathrm{HbA}_{1 \mathrm{c}}$, glycated haemoglobin; $\mathrm{OAD}$, oral antidiabetic drug; $\mathrm{SS}$, sliding scale.}

53-64 $\mathrm{mmol} / \mathrm{mol}$ in functionally dependent older adults, with lenience to $<70 \mathrm{mmol} / \mathrm{mol}$ in those frail or living with dementia, ${ }^{9}$ this suggests significant overtreatment of this population cohort.

Interestingly, higher $\mathrm{HbA}_{1 \mathrm{c}}$ levels were also associated with an increased risk of developing hypoglycaemia, $10,13,14$ reflecting poor glycaemic control at both ends of the $\mathrm{HbA}_{1 \mathrm{c}}$ spectrum. $\mathrm{HbA}_{1 \mathrm{c}}$ is a poor marker of glucose variability and needs to be interpreted cautiously in older adults (especially those dependent on carers for nutrition and injectable therapy) due to their susceptibility to $B G$ fluctuation. $\mathrm{HbA}_{1 \mathrm{c}}$ levels can also be falsely high or low due to anaemia, polycythaemia or renal impairment, which become more prevalent with ageing. Andreassen et a/ ${ }^{19}$ found capillary BG measurements to have a broader reach in identifying older adults at risk of developing hypoglycaemia than $\mathrm{HbA}_{1 \mathrm{c}}$ levels.

We identified 10 observational studies which have reported on the prevalence of hypoglycaemia in aged-care facility residents. The prevalence of hypoglycaemia based on these studies ranged from $6.6 \%$ to $60 \%, 10,11,13,14,16,18,19,24,26,27$ reflecting it to be a common and avoidable risk factor associated with increased morbidity in this age group. Indeed, of the 44 nursing homes approached by Hurley et al, 19\% reported hypoglycaemic evens as "frequent" among its residents. ${ }^{28}$

Insulin therapy was commonly associated with the greatest risk of hypoglycaemia compared with other treatment modali- ties, $10,11,13,14,16,24,27$ highlighting this therapy as the most in need of review and simplification. An exception to this was a study by Abbatecola et al who observed a lower risk of severe hypoglycaemia associated with rapid and analogue insulin (OR 0.333, 95\% $\mathrm{Cl} 0.184$ to 0.602 and OR $0.248,95 \% \mathrm{Cl} 0.070$ to 0.882 , respectively) compared with sulfonylurea therapy (OR $8.8,95 \% \mathrm{Cl} 4.2$ to 18.2) ${ }^{18}$ This study also reported residents with dementia (18\%) to be especially vulnerable to developing severe hypoglycaemia compared with residents without dementia (8\%). ${ }^{18}$ Multiple other studies have reported an increased risk of sulfonylurea-induced hypoglycaemia in residents with dementia. ${ }^{16,18}$

\section{Part B: Simplification of T2DM treatment in residents of aged-care facilities}

There is limited literature exploring simplification of T2DM treatment in this population. We identified three such studies which provide a regimen for simplification of T2DM management in residents of aged-care facilities. These studies showed marked heterogeneity in population selection, intervention used for simplification and reported outcomes, making direct comparison non-viable. For example, Sjoblom et al explored different strategies for simplification including switching insulin to oral antidiabetic drugs, cessation of insulin $<20$ units and halving of insulin $>20$ units. ${ }^{21}$ Dharmarajan et al explored simplifying insulin regimens from sliding scale (SS) to 
Figure 2. Forest plot showing mean $\mathrm{HbA}_{1 \mathrm{c}}$ and $95 \%$ confidence intervals $(\mathrm{Cl})$ of aged-care facility residents with diabetes. Overall pooled studies mean $51.9 \mathrm{mmol} / \mathrm{mol}(95 \% \mathrm{Cl} 51.8$ to 52.0$)$.

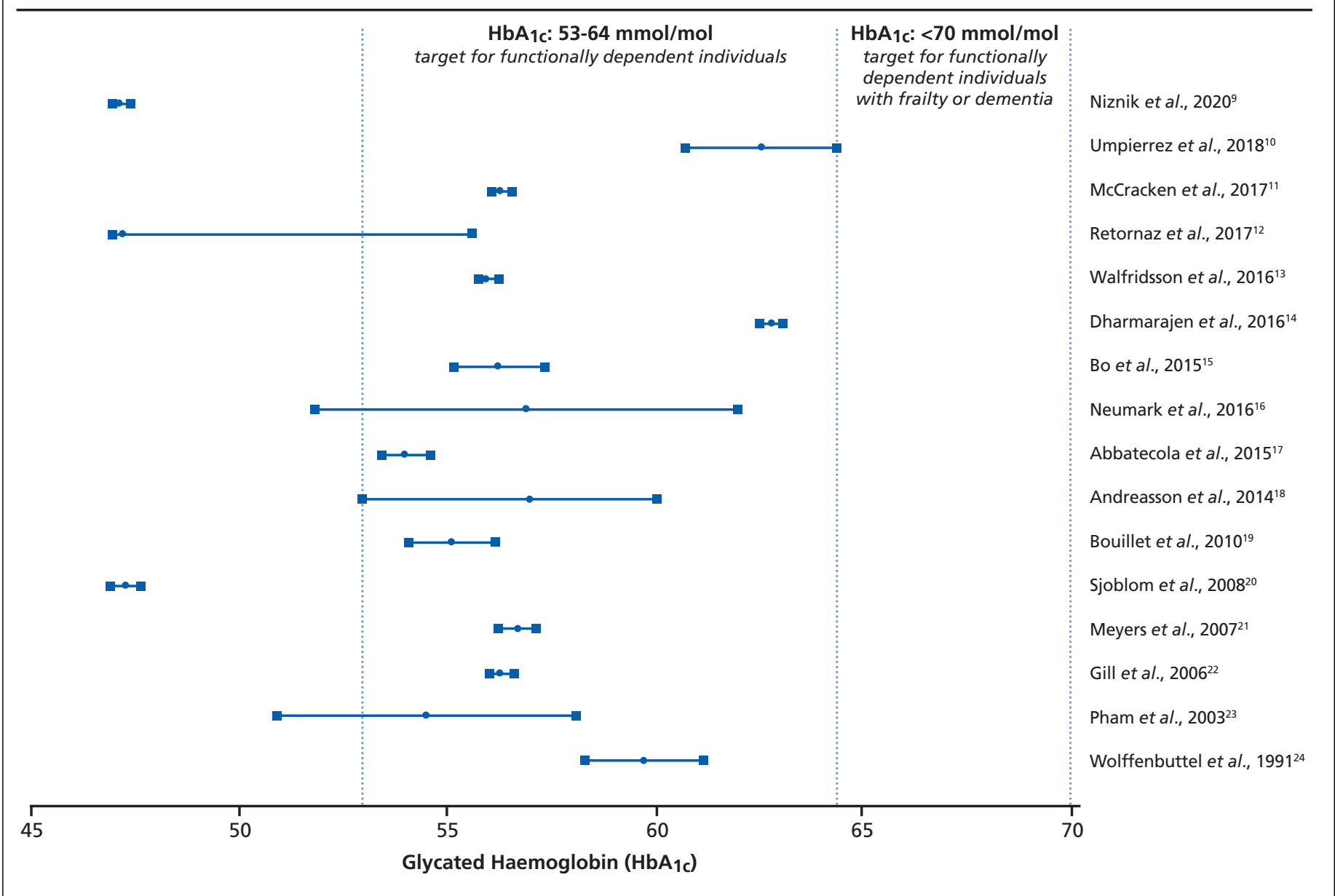

basal bolus (BB). ${ }^{15}$ A study by Umpierrez et a/ was the only one to compare basal insulin (glargine) with DPP4 inhibitor (linagliptin) monotherapy. ${ }^{11}$

Of the two studies reporting BG levels, both showed reduced glycaemic variability with simplified treatment. For example, compared with baseline, linagliptin monotherapy resulted in significantly lower mean daily BG. ${ }^{11}$ A 34\% absolute risk reduction in residents affected by hypoglycaemia was also demonstrated when compared with those receiving insulin. ${ }^{11}$ Similarly, Dharmarajan et al demonstrated significantly lower fasting BG in those on BB insulin regimens compared with SS. ${ }^{15}$ Here, there were no significant differences in the incidence of hypoglycaemia, although data collection for this occurred over a three-day period only. ${ }^{15}$

Two of the studies used $\mathrm{HbA}_{1 \mathrm{c}}$ to report the impact of simplification on glycaemic control. Although Sjoblom et al reported a 7 $\mathrm{mmol} / \mathrm{mol}$ mean $\mathrm{HbA}_{1 \mathrm{c}}$ increase, the 6-month post-intervention mean remained low at $40 \mathrm{mmol} / \mathrm{mol} .{ }^{21}$ When compared with insulin therapy, linagliptin showed no significant difference in $\mathrm{HbA}_{1 \mathrm{c}}$ at 6 months. ${ }^{11}$ In addition, simplification caused no significant changes to all-cause hospital admissions ${ }^{11,21}$ or mortality. ${ }^{21}$

Our systematic review of the literature provides further evidence to support a well-formed consensus: residents with T2DM in aged- care facilities are often subject to intensive glycaemic control and hypoglycaemia. In older adults with T2DM, intensive glycaemic control, especially hypoglycaemia, contributes to accelerated physical and cognitive decline, hospital admissions, frailty and reduced life expectancy. ${ }^{4}$ Although limited by scarcity of randomised controlled trials, this review suggests that simplification of T2DM treatment can effectively reduce hypoglycaemia risk without compromising glycaemic control in this population. ${ }^{11,15,21}$ Additionally, simplification may also benefit QOL by reducing tablet, injection and BG monitoring burden for both residents and carers. ${ }^{29}$

\section{Part C: Identification of residents most likely to benefit from simplification of T2DM treatment}

Identifying aged-care facility residents most likely to benefit from simplification of therapy has not received much focus. Evaluating glycaemic control in this cohort is challenging as factors such as cognitive impairment, frailty, reduced functional reserve and depression may make self-monitoring of $B G$ and reporting of osmotic symptoms difficult.

$\mathrm{HbA}_{1 \mathrm{c}}$ measurement remains a relatively insensitive tool to screen those at risk of developing hypoglycaemia. ${ }^{10,13,14}$ Capillary BG monitoring should supplement $\mathrm{HbA}_{1 \mathrm{c}}$ monitoring in identifying 


\section{Key messages}

- Hypoglycaemia is a common and preventable cause of increased morbidity and mortality in residents of aged-care facilities

- Capillary blood glucose monitoring should supplement $\mathrm{HbA}_{1 \mathrm{c}}$ monitoring in evaluating glycaemic control in frail adults

- Continuous glucose monitoring in older adults deemed at high risk of hypoglycaemia offers a novel and pragmatic approach with potential to improve quality of life

- Simplification of type 2 diabetes therapy should be considered in most residents of aged-care facilities, especially in the presence of frailty and dementia

older adults most vulnerable to develop hypoglycaemia. Short- or medium-term continuous glucose monitoring in aged-care facility residents deemed at high risk of hypoglycaemia offers a pragmatic approach and a far more comprehensive reflection of glycaemic control.

The number of antidiabetic prescriptions has not been observed to show correlation with hypoglycaemia risk. ${ }^{12}$ Care is needed to avoid cessation of insulin in those with type I diabetes mellitus or Latent Autoimmune Diabetes of Adulthood (LADA). As such, further work is needed to explore whether an insulinopenic phenotype as suggested by history, low or low-normal body mass index, previous diabetic ketoacidosis, presence of anti-GAD or anti-islet cell antibodies or strong personal history of autoimmune conditions correctly identifies those with insulin dependency. Similarly, preserved urinary C-peptide:creatinine can give biochemical reassurance of residual pancreatic $\beta$ cell function and confidence to simplify diabetic treatment.

Selecting a safe and individualised regimen for simplification remains integral in delivering biological, not chronological, patientcentred care - a principal central to all discussions in this review.

\section{Conclusions}

In summary, simplification of treatment should be considered in most residents with T2DM living in aged-care facilities, especially in the presence of dementia and frailty. Treatment regimens need to be individualised with simplification of the insulin regimen and/or switching to oral glucose-lowering medications wherever possible. At the time of writing this review, the COVID-19 pandemic reminds us that keeping our older adults with diabetes safe, reducing their dependence on caregivers for administration of tablets, injections and BG monitoring, is far more important now than it has been ever before.

\section{Conflict of interest None. Funding None.}

\section{References}

1. Gojka R. WHO Global report on diabetes: a summary. Int I Noncommun Dis 2016;1(1):3-8.

2. Diabetes UK. How many people are at risk of type 2 diabetes? London: The British Diabetic Association. 2019. Available at: https://www. diabetes.org.uk/ about_us/news/new-stats-people-living-with-diabetes (accessed 6 May 2020).

3. Diabetes UK. Diabetes in the UK 2010: Key statistics on diabetes 2010. Available at: https://www.diabetes.org.uk/resources-s3/2017-11/ diabetes_in_the_uk_2010.pdf (accessed 5 May 2020).

4. Sinclair AJ, Gadsby R, Abdelhafiz AH, Kennedy M. Failing to meet the needs of generations of care home residents with diabetes: a review of the literature and a call for action. Diabet Med 2018;35(9):1144-56. https://doi.org/10.1111/dme.13702

5. Dunning T, Sinclair A, Colagiuri S. New IDF guideline for managing type 2 diabetes in older people. Diabetes Res Clin Pract 2014;103(3):538-40. https://doi.org/10.1016/j.diabres.2014.03.005

6. American Diabetes Association. 12. Older Adults: Standards of Medical Care in Diabetes-2020. Diabetes Care 2020;43(Suppl 1):S152-S162. https://doi.org/10.2337/dc20-S012

7. Ryan R, Synnot A, Prictor M, Hill S. Data extraction template for included studies. 2016. Available at: https://figshare.com/articles/Data_extraction_template/ 6818852 (accessed 30 April 2020)

8. Critical Appraisal Skills Programme. CASP Checklists. 2018. Available at: https://casp-uk.net/casp-tools-checklists/ (accessed 30 April 2020).

9. Moher D, Liberati A, Tetzlaff J, Altman DG. Preferred reporting items for systematic reviews and meta- analyses: the PRISMA statement. BMJ 2009;339:b2535. https://doi.org/10.1136/bmj.b2535

10. Niznik JD, Hunnicutt JN, Zhao X, et al. Deintensification of diabetes medications among Veterans at the end of life in VA nursing homes. J Am Geriatr Soc 2020;68(4):736-45. https://doi.org/10.1111/jgs.16360

11. Umpierrez GE, Cardona $S$, Chachkhiani $D$, et al. A randomized controlled study comparing a DPP4 inhibitor (linagliptin) and basal insulin (glargine) in patients with type 2 diabetes in long-term care and skilled nursing facilities: Linagliptin-LTC Trial. J Am Med Dir Assoc 2018;19(5):399-404.e3. https://doi.org/10.1016/j.jamda.2017.11.002

12 McCracken R, McCormack J, McGregor MJ, et al. Associations between polypharmacy and treatment intensity for hypertension and diabetes: a cross-sectional study of nursing home patients in British Columbia, Canada. BMJ Open 2017;7(8):e017430. https://doi.org/10.1136/bmjopen-2017017430

13. Retornaz F, Grino M, Mari L, Oliver C. Assessment of glycemic control in nursing home residents with diabetes. I Nutr Health Aging 2017; 21(4):457-63. https://doi.org/10.1007/s12603-016-0776-0

14. Walfridsson A, Sehlberg M, Gillespie $U$, et al. Diabetes treatment and hypoglycaemic episodes in elderly patients at nursing homes in Uppsala County. Uppsala J Med Sci 2016;121(3):179-83. https://doi.org/ 10.1080/03009734.2016.1198441

15. Dharmarajan TS, Mahajan D, Zambrano A, et al. Sliding scale insulin vs basalbolus insulin therapy in long-term care: a 21-day randomized controlled trial comparing efficacy, safety and feasibility. J Am Med Dir Assoc 2016; 17(3):206-13. https://doi.org/10.1016/j.jamda.2015.08.015

16. Bo M, Gallo S, Zanocchi M, et al. Prevalence, clinical correlates, and use of glucose-lowering drugs among older patients with type 2 diabetes living in long-term care facilities. J Diabetes Res 2015;2015:174316. https://doi.org/ $10.1155 / 2015 / 174316$

17. Neumark A-SN, Brudin L, Neumark T. Adherence to national diabetes guidelines through monitoring quality indicators- $\mathrm{A}$ comparison of three types of care for the elderly with special emphasis on HbA1c. Primary Care Diabetes 2015;9(4):253-60. https://doi.org/10.1016/j.pcd.2015.03.002

18. Abbatecola AM, Bo M, Barbagallo M, et al. Severe hypoglycemia is associated with antidiabetic oral treatment compared with insulin analogs in nursing home patients with type 2 diabetes and dementia: results from the DIMORA Study. J Am Med Dir Assoc 2015;16(4):349.e7-e12. https://doi.org/10.1016/j.jamda.2014.12.014

19. Andreassen LM, Sandberg S, Kristensen GBB, et al. Nursing home patients with diabetes: prevalence, drug treatment and glycemic control. Diabetes Res Clin Pract 2014;105(1):102-09. https://doi.org/10.1016/ j.diabres.2014.04.012 
20. Bouillet $B$, Vaillant $G$, Petit JM, et al. Are elderly patients with diabetes being overtreated in French long-term-care homes? Diabetes Metab 2010; 36(4):272-7. https://doi.org/10.1016/j.diabet.2010.01.009

21. Sjöblom P, Anderstengblad U-B, Löfgren C, et al. Can diabetes medication be reduced in elderly patients? An observational study of diabetes drug withdrawal in nursing home patients with tight glycaemic control. Diabetes Res Clin Pract 2008;82(2):197-202. https://doi.org/10.1016/ j.diabres.2008.08.014

22. Meyers RM, Broton JC, Woo-Rippe KW, et al. Variability in glycosylated hemoglobin values in diabetic patients living in long-term care facilities. J Am Med Dir Assoc 2007;8(8):511-14. https://doi.org/10.1016/ j.jamda.2007.02.002

23. Gill EA, Corwin PA, Mangin DA, Sutherland MG. Diabetes care in rest homes in Christchurch, New Zealand. Diabet Med 2006;23(11):1252-6. https://doi.org/10.1111/j.1464-5491.2006.01976.x

24. Pham M, Pinganaud G, Richard-Harston S, et al. Prospective audit of diabetes care and outcomes in a group of geriatric French care homes. Diabetes Metab 2003;29(3):251-8. https://doi.org/10.1016/s12623636(07)70034-4

25. Wolffenbuttel BHR, van Vliet S, Knols AJF, et al. Clinical characteristics and management of diabetic patients residing in a nursing home. Diabetes Res Clin Pract 1991;13(3):199-206. https://doi.org/10.1016/01688227(91)90064-k

26. Davis KL, Wei W, Meyers JL, et al. Use of basal insulin and the associated clinical outcomes among elderly nursing home residents with type 2 diabetes mellitus: a retrospective chart review study. Clin Interv Aging 2014;9:181522. https://doi.org/10.2147/CIA.S65411

27. Newton CA, Adeel S, Sadeghi-Yarandi S, et al. Prevalence, quality of care, and complications in long term care residents with diabetes: a multicenter observational study. J Am Med Dir Assoc 2013;14(11):842-6. https://doi.org/10.1016/j.jamda.2013.08.001

28. Hurley L, O'Donnell M, O'Caoimh R, Dinneen SF. Investigating the management of diabetes in nursing homes using a mixed methods approach. Diabetes Res Clin Pract 2017;127:156-62. https://doi.org/10.1016/ j.diabres.2017.03.010

29. Barnhart C, McClymont K, Smith AK, et al. "Everyone else gets ice cream here more often than I do--It burns me up"-perspectives on diabetes care from nursing home residents and their doctors. BMC Geriatrics 2016;16:28. https://doi.org/10.1186/s12877-016-0199-0

\section{Q Air Liquide H E A L T H C A R E \\ $t: \operatorname{sim} \times 2$ \\ Insulin Pump

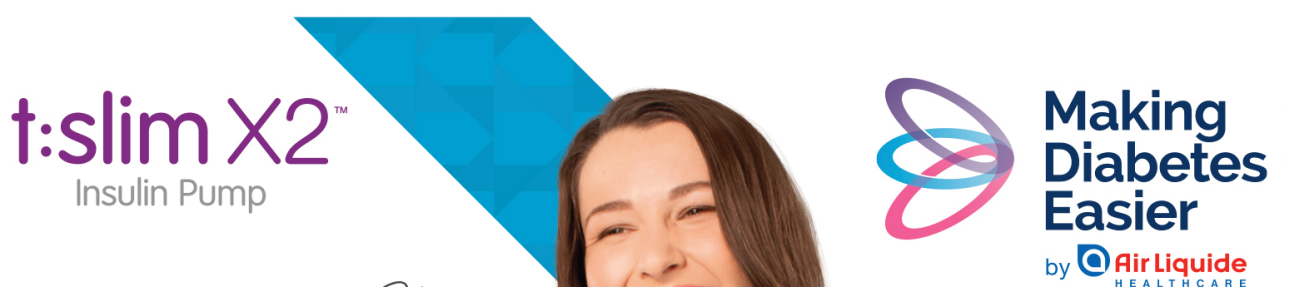 \\ (9) \\ by Air Liquide}

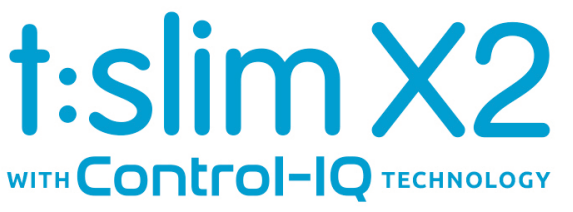

Control-IQTM advanced hybrid closed-loop technology on the t:slim X2 $2^{\text {TM }}$ insulin pump predicts and helps reduce highs and lows to help increase time in range.*

Control-IQ Technology is designed to help increase time in range (3.9-10.0 mmol/L)* using Dexcom G6 continuous glucose monitoring (CGM) values to predict glucose levels 30 minutes ahead and adjust insulin delivery accordingly; including delivery of automatic correction bolusest (up to one per hour).

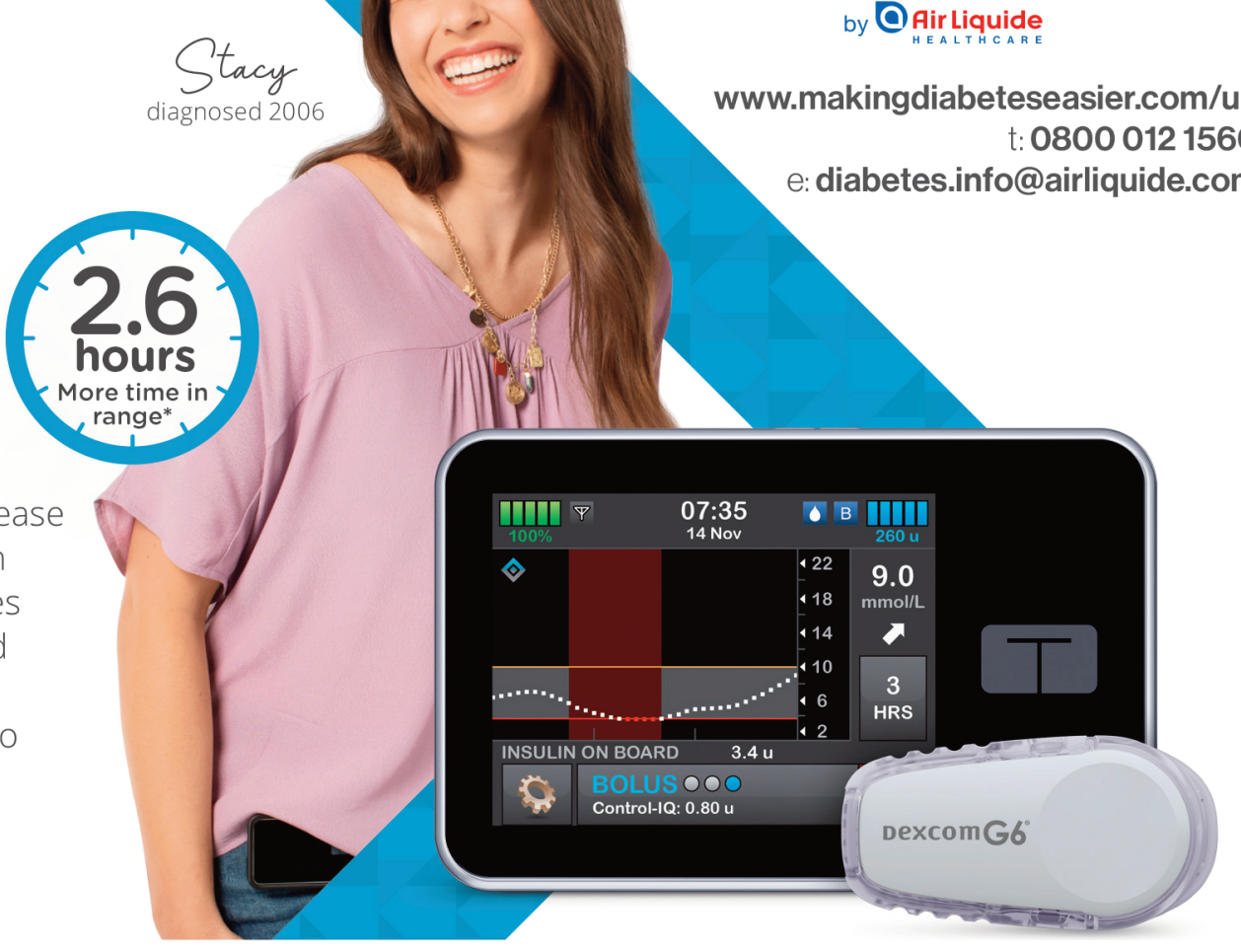

Responsible Use of Control-IQ" Technology

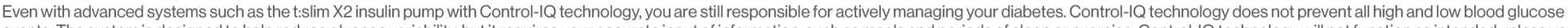

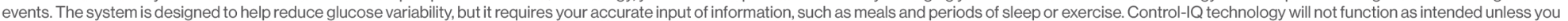

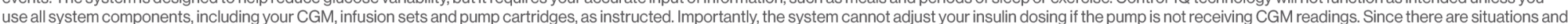
emergencies that the system may not be capable of identifying or addressing, always pay attention to your symptoms and treat according to your healthcare provider's recommendations.

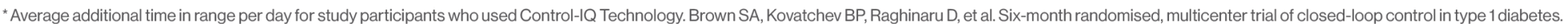
N Eng J Med. 2019;381(18):1701-1717. 
Appendix 1. Full MEDLINE search

-

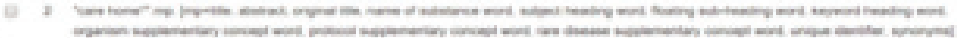

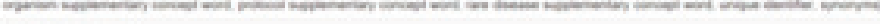

3 nestoron

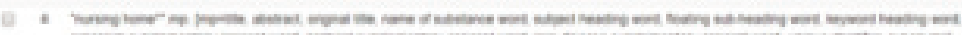

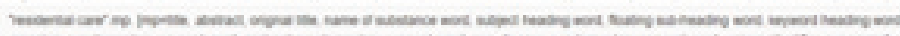

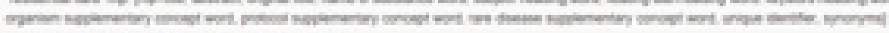

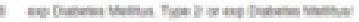

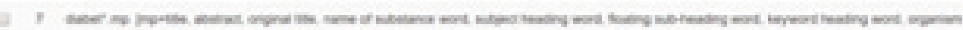

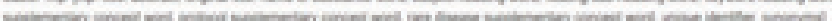

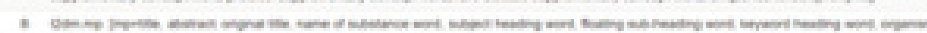

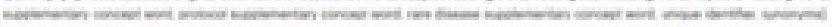

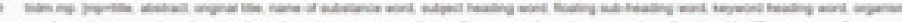

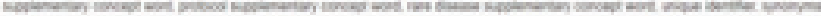

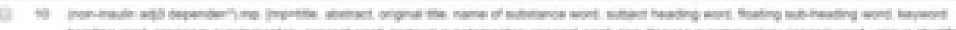

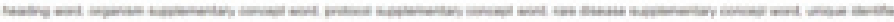

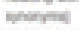

D. $n$ mesmins

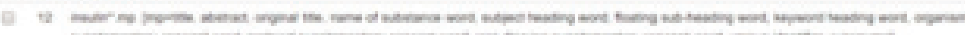
26е

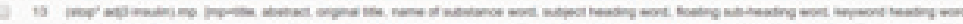

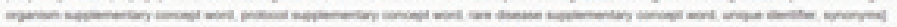

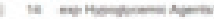

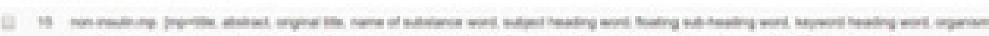

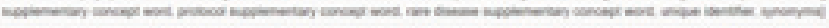

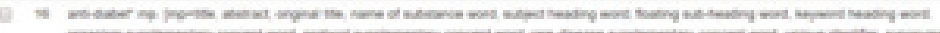

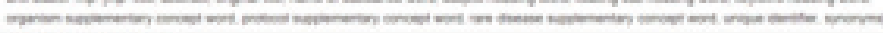

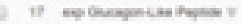

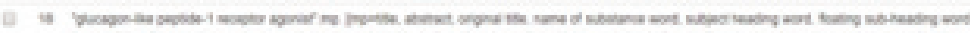

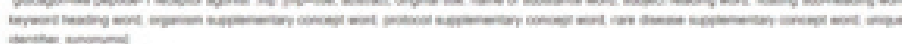

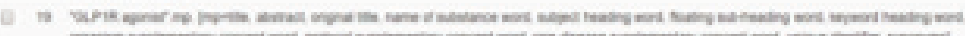

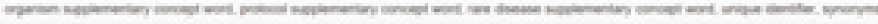

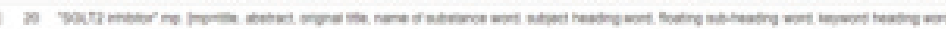

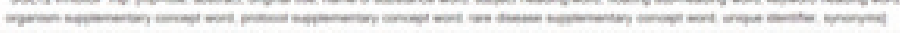

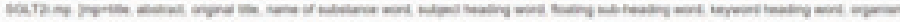

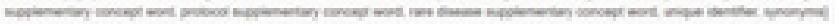

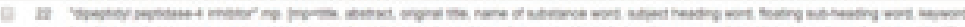

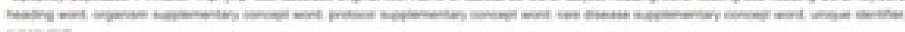
(nomest

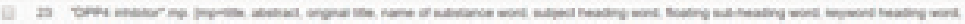

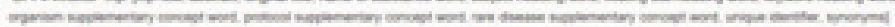

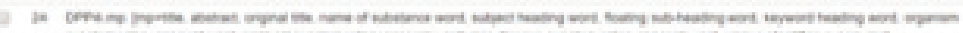

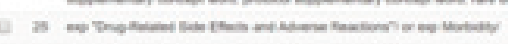

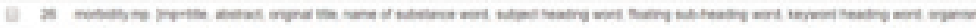

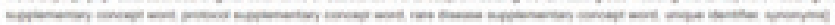

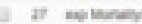

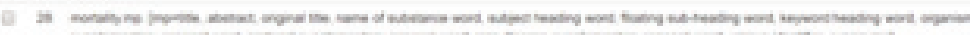

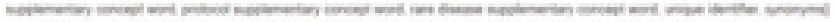

is $=0$

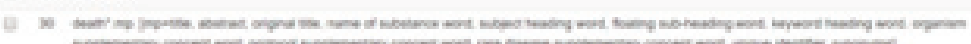

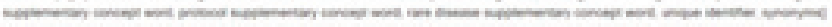

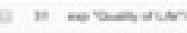

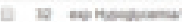

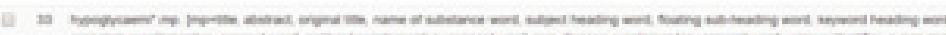

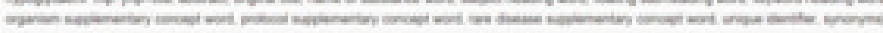

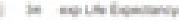

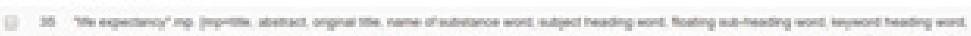

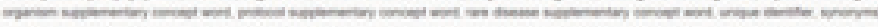

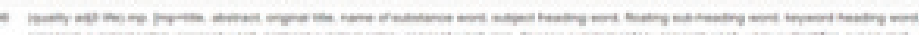

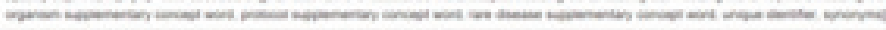

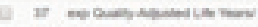

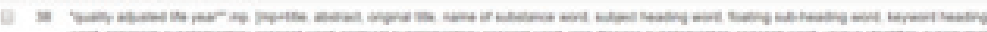

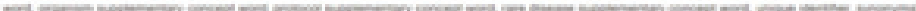

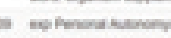

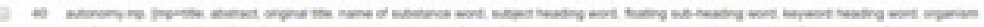

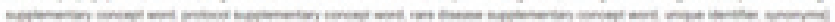

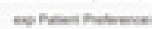

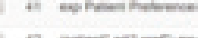

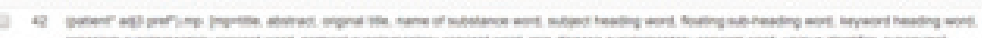

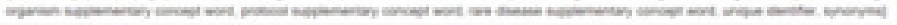

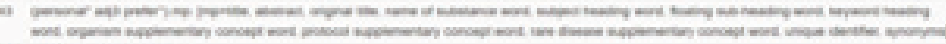

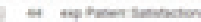

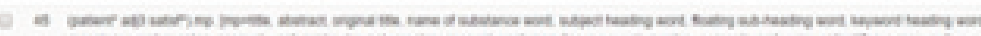

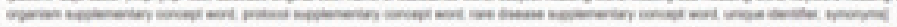

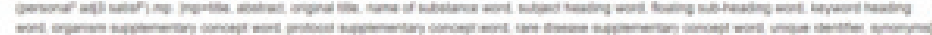
ieisesent

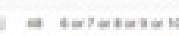

a "

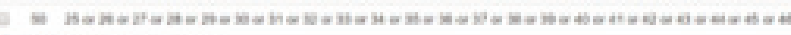

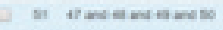

4hos

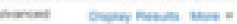

nanom

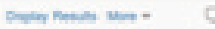

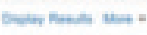

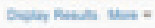

aherem

nenences

nones

neweres

nowerest

nimen

nement

Sencoses

merem

nereert

Nemenet

anowest

acowest

namos

noment

naver

acheret

nament

nower

Anereat

nemere

nover

nement

neveret

nemenes

newerest

nement

naveret

navest

nemen

nament

namere

nement

nomedes

nemenes

atsonet

nenenet

nement

nenerot

nement

neneret

nament

nement

noment

nenent

niment

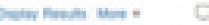

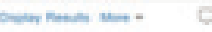

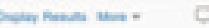

Sow knot thes to

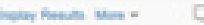

Gow towes un: C

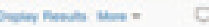

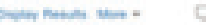

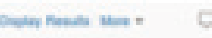

Gow newe ven: C

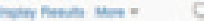

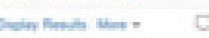

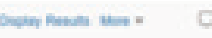

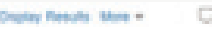

Newners un. C

Down newo ven: C

Oner now un.

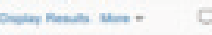

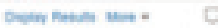

Devernow une. C

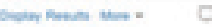

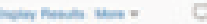

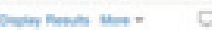

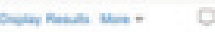

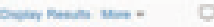

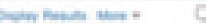

Down fous uns C

onernow un: C

Soy nowis us.

owernens ans. C

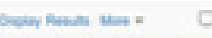

Dow towas ven. C

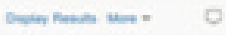

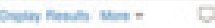

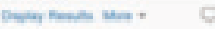

Deow hewe mos: C

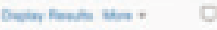

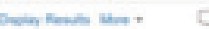

Dempons mon

Downew mon C

Demprous mo: C

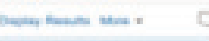

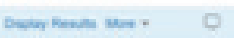

Nownen uns : C

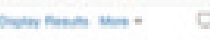

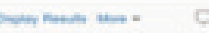

